International Journal of

MULTILINGUAL

MULTILINGUAL EDUCATION

EDUCATION

ISSN: (Print) ISSN 1987-9601

(Online) E ISSN 1512-3146

Journal homepage: http://multilingualeducation.org/

\title{
General linguistic aspects of borrowed Svan vocabulary
}

\author{
Medea Sagliani \\ $\mathrm{PhD}$ in Philology \\ Arnold Chikobava Institute of Linguistics, \\ TSU; Researcher \\ Email: medeasagliani@yahoo.com
}

To cite this article: Medea Sagliani (2021) General linguistic aspects of borrowed Svan vocabulary:

International Journal of MultilingualEducation, \#19; pp. 16-25.

DOI:10.22333/ijme.2021.19003

To link to this article: https://doi.org/10.22333/ijme.2021.19003 


\title{
Medea Sagliani
}

Arnold Chikobava Institute of Linguistics,

Ivane Javakhishvili Tbilisi State University, Tbilisi, Georgia

\section{General Linguistic Aspects of Borrowed Svan Vocabulary ${ }^{1}$}

\begin{abstract}
This paper presents general conclusions on all aspects related to word borrowing, taking into account the borrowing-adaptation of foreign-language lexical units assimilated into Svan from Georgian- Zan, as well as North Caucasus, Western European, Russian and Eastern languages (directly or indirectly), to determine the ways and chronology of borrowings, which is very important and interesting to present a general picture of the development of Svan phonological and lexical systems. The study of borrowed material of Svan, as it has been said many times, will once again support the opinion recognized in Kartvelology for the great (sometimes decisive) importance of the grammatical phenomena of Svan in solving a number of linguistic problems.
\end{abstract}

Keywords: Vocabulary, Phonetics, Semantics

In Svan, as in any language (unwritten or written), words borrowing is one of the main sources of vocabulary enrichment. The possibility of making this conclusion was provided by the analysis of great illustrative material, which we conducted on the example of simple roots or composites according to the data of traditionally known dialects of Svan (Upper Bal, Lower Bal, Lashkhian and Lentekhian) and Cholur speech.

This paper presents general conclusions on all aspects related to words borrowing, taking into account the borrowing-adaptation of foreign- language lexical units assimilated into Svan from Georgian-Zan, as well as North Caucasus, Western European, Russian and Eastern languages (directly or indirectly), to determine the ways and chronology of borrowings, which is very important and interesting to present a general picture of the development of Svan phonological and lexical systems. The study of borrowed Svan material, as it has been said many times, will once again support the opinion recognized in Kartvelology for the great (sometimes decisive) importance of the grammatical phenomena of 
Svan in solving a number of linguistic problems.

As research has shown, borrowed Svan vocabulary includes many examples of North Caucasian (Kabardian, Circassian, Abkhazian, Ossetian ...), Western European (Greek, Latin), Russian and Eastern (Turkish, Persian, Arabic, Armenian) languages, which is due to certain contacts in time and space... Alongside, of course, there are borrowings related to Kartvelian languages (Georgian, Mingrelian, Laz), the common Kartvelian data of which is not always easy to separate, however, as it is known, the situation arising from language contacts differs substantially from the post-differentiation situation... As a result of borrowing and adaptation (interference) we do not get regular phonetic correspondence" (Machavariani 1965: 49). Since such correspondence, with a few exceptions, so far only deals with sibilants, Zan vowels transitions (Georgian a - Zan - o, Georgian - e, Zan a) can be used as a means of control. Here, of course, borrowing is out of the question, where so-called Zan vowels transitions are evidenced. At the same time, it should be taken into account whether this or that particular lexeme is represented in old Georgian written monuments. In case of a positive answer, probebility of borrowing from Georgian into Svan are less confirmed, especially if the vowels correspondence will be revealed in Mingrelian.

It turns out that the roots of foreign language lexemes are confirmed as phoneticallysemantically unchanged in Svan (e.g.: so̊s6m abano (Upper Svan, Lower Svan) < Georgian

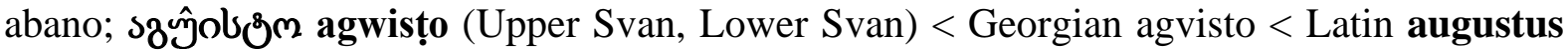
"saint, divine, great"; smyzbsm alubal (Upper Svan, Lower Svan) < Georgian alubal-i; s63jl

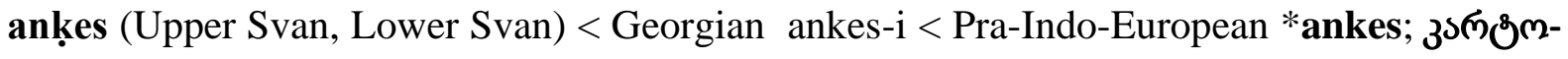
ஜुom karțopil (Lower Bal) < Georgian kartopil-i < Russian Картофель < German

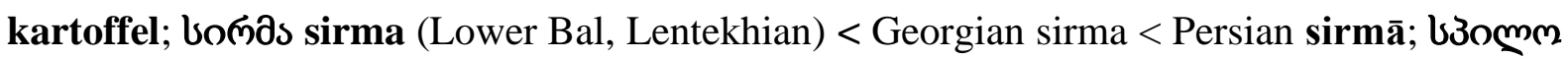
spilo (Upper Svan, Lower Svan) < Georgian spilo < Pahlavi pīl; ơo6on pint (Upper Svan, Lower Svan) < Georgian (Gurian, Kartlian, Kiziqian) pint-i < Ossetian fyd "avi, tsudi" "wicked, bad"; ysmsymen garaul (Lower Bal) < Georgian karaul-i < Turkish - karawul; bsen xal (Upper Svan) < Georgian khal-i - < Arabic hāl; żõ žiš (Upper Svan, Lower Svan) < Georgian jish- i < Arabic Jins and etc.), so with different phonetic variants (e.g.: Bsmsf barak (Upper Bal, Lower Svan) < Georgian baraka < Arabic baraq; Зо๓мठ pirob (Upper

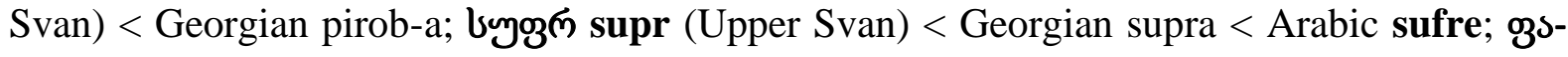
ms6z palang (Upper Svan, Lashkhian) < Georgian (Lechkhumian, Rachian, Imeretian) 
palanga "a pole (for hanging something)" < Persian palanga; ๓oy rig (Upper Svan, Lower

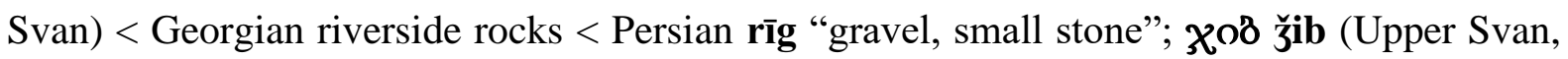
Lentekhian) < Georgian jibe < Persian (<Arabic) $\mathbf{J}<\mathbf{b}$; om Georgian tokalto < Persian tukaltu; mgjn okr (Lower Bal) < Georgian okro < Greek oxpos

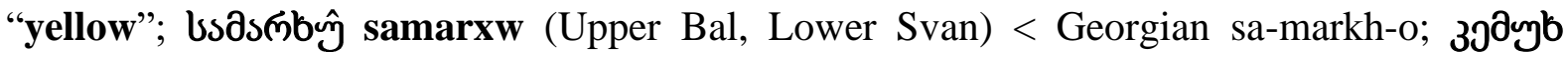
ḳemux (Upper Bal) "book cover” < Georgian kemukht-i "leather”; dmsb moax (Lentekhian) < Georgian moakhle; ŷ̂̃o gwič (Upper Svan, Lower Svan) "cock” - Georgian kvinchila...) or in the context of data modified by semantic nuances (e.g. зऽलॄasb kalmax (Upper Svan,

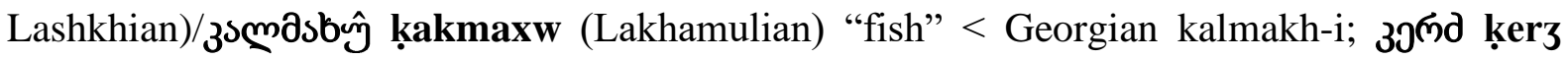
(Lower Svan) "friend, relative" > Old Georgian kerdz-i, kerdzo < Ossetian kærd; зоп் $\hat{y}$ ḳiraw (Lower Svan) "wattle building” > karav-i; asbœo૩3 masdiḳ (Upper Svan) "hurtful, offence, grief" < Georgian sisastike < Pahlavi "strong, firm, severe"; ä̋øৎsб mäjdan (Upper Svan) "the door of balcony" < Georgian moedan-i < Persian maydān; bsyœ saud (Upper

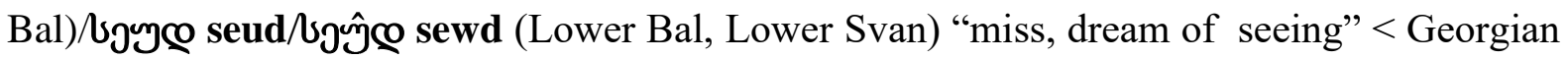
sevda < Arabic-Persian souda; fom ç̣ir (Upper Svan, Lentekhian) "to work, to take some pains, heavy work" < Georgian chir-i and etc.).

Some borrowed roots are "Svaned", it means they contain morphonological inventory

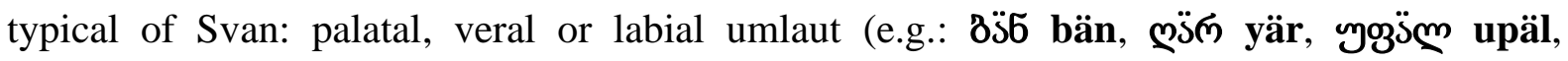

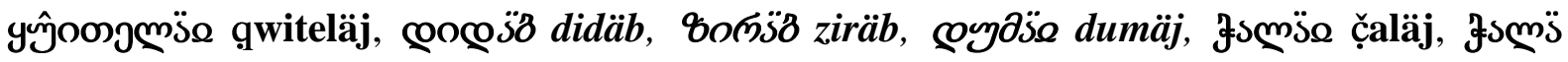

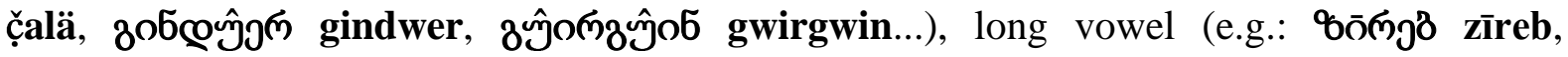

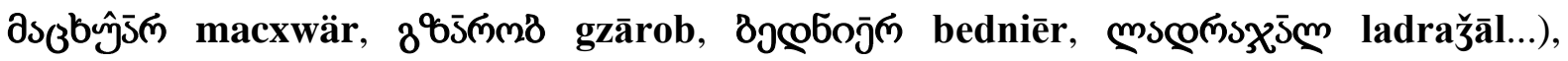

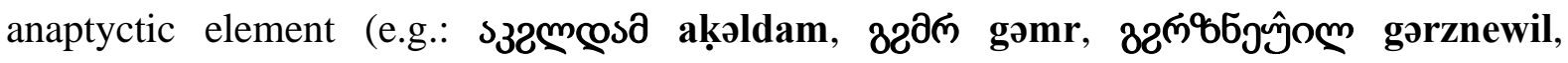

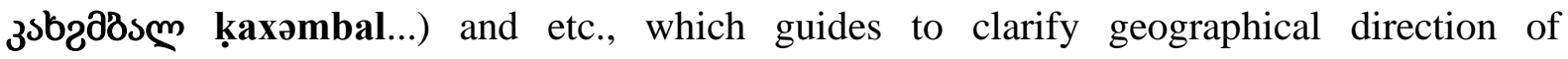

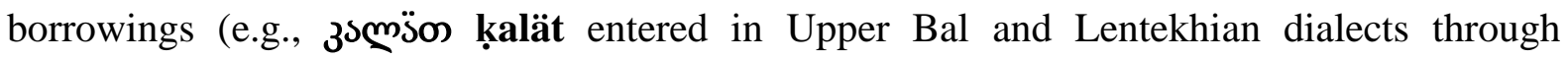
Georgian, this is confirmed by the last vowel umlaut, which is the trace of the loss of nominative case morpheme; the original Greek $\boldsymbol{\kappa} \boldsymbol{\alpha} \lambda \boldsymbol{\alpha} \zeta \boldsymbol{\alpha}$ is preserved only in Georgian).

Sometimes the root borrowed from Georgian is so "Svaned" that quite complex phonological transformations are taken into account to restore the original version: e.g.:

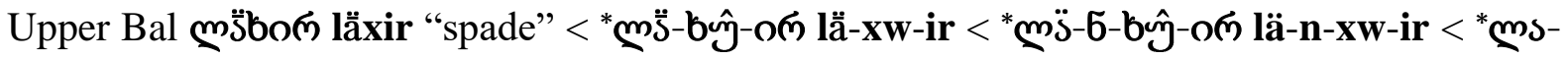




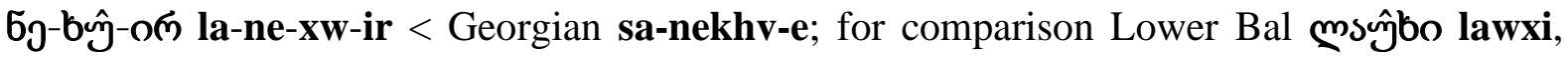

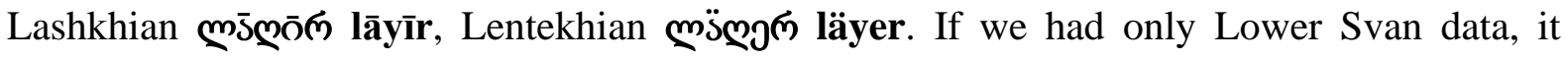
would probably be difficult to connect this root to Georgian root "nekhv". Upper Bal

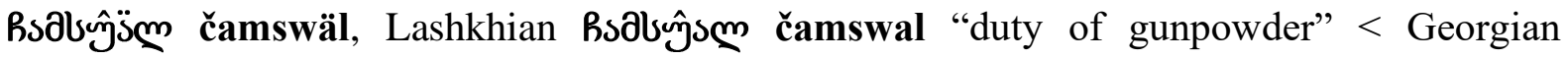

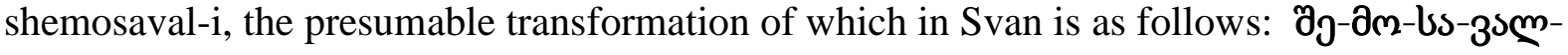

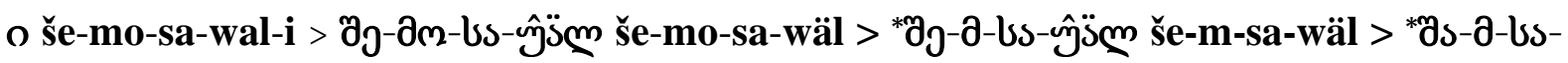

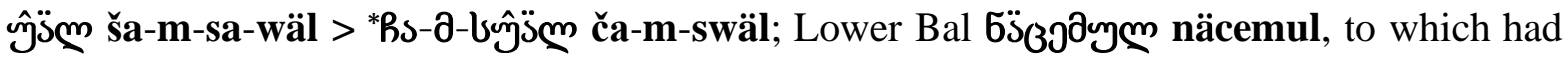
to go through a rather complicated phonological transformation from Georgian form

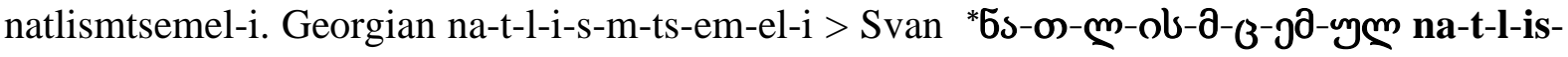
m-c-em-ul > ${ }^{*} 6 s-\infty-m-o b-\left(\jmath^{\partial-y}\right.$ -

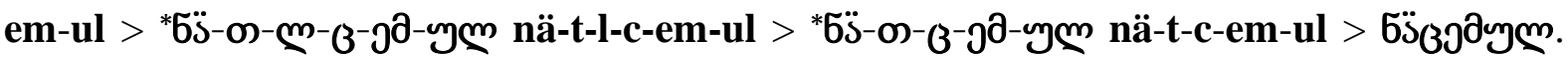
The stages of phonological evolution of the relevant "soul mentioning" Svan term is particularly interesting in respect of the precedence-posterior of complex transformations:

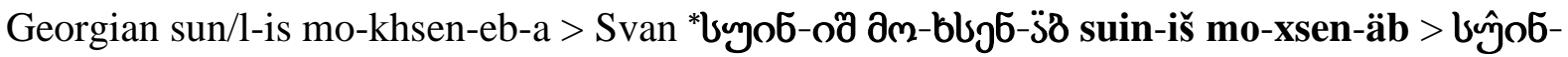

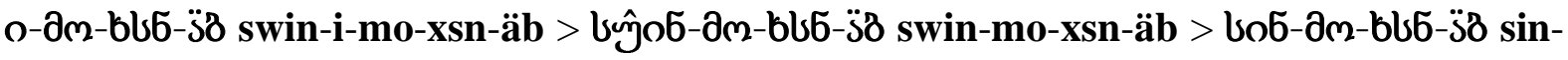

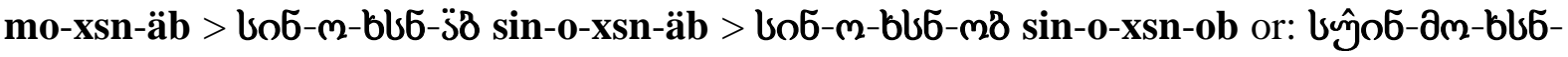

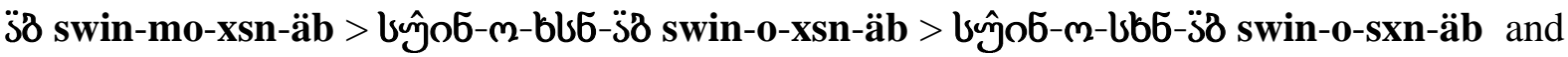
etc.

One extremely well-defined tendency of auslaut nature of Svan names transformation open-syllables structures into closed-syllables ones is most often expressed in borrowed stems ( (Lentekhian) < Georgian khelmtsipe; bsfึyom saçutr (Lashkhian) < Old Georgian satsutro; sдљ̋̈ ambä (Lower Bal) < Georgian ambav-i < Pahlavi hambav; dmsb moax (Lentekhian) <

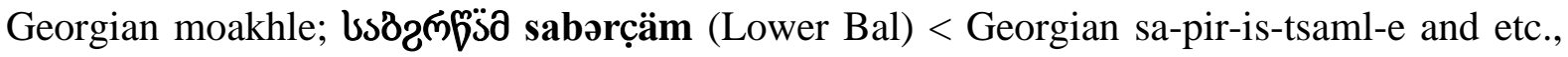
which implies simplification of forms.

in most borrowed Svan words there are the compensatory ones obtained as a result of

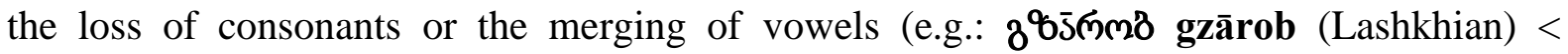

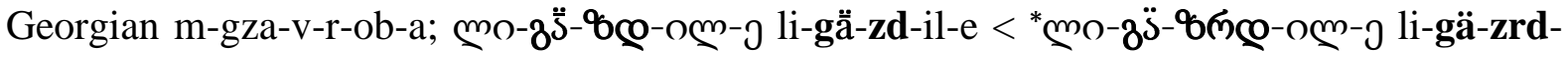

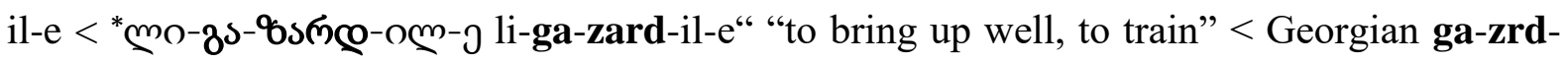

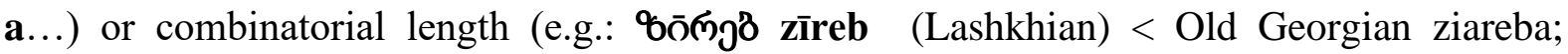




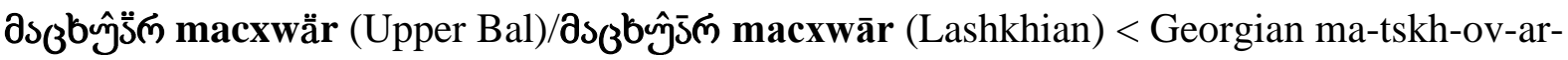
i...), deaffrication-spirantization (e.g.: \$8s 6 jos bzaneba (Upper Bal) < Georgian brdzan-eb-

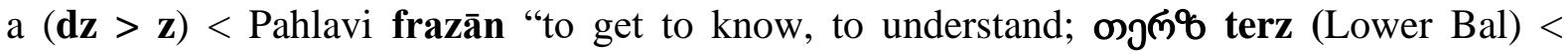

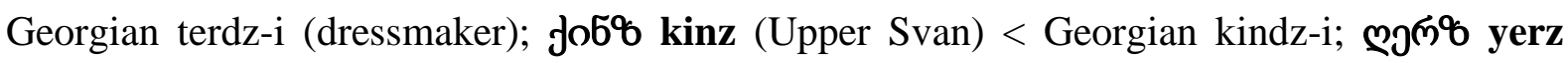

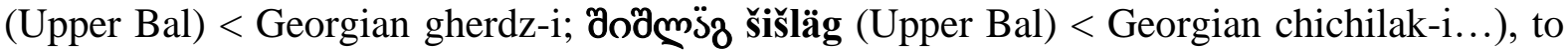
make consonats voiced (e.g.: s\&̣̈̋ azäd (Lakhamulian) < Georgian azat-i "free peasant" <

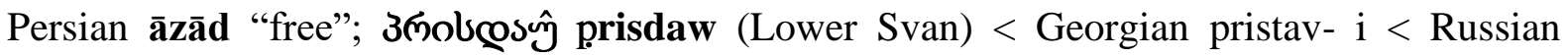
пристав; уӟз qäక̆ (Upper Svan) < Old Georgian kach-i...), alternation of sonant consonants (e.g.: Øsð̋̈m šašäl (Lower Bal) "blow" < Georgian (Pshavian, Kiziqian) sha-shar-i "sword

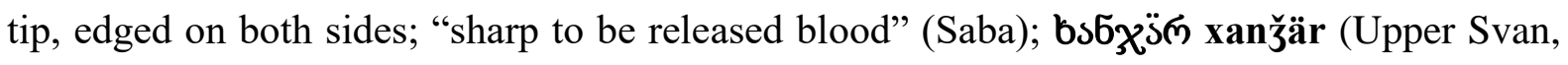

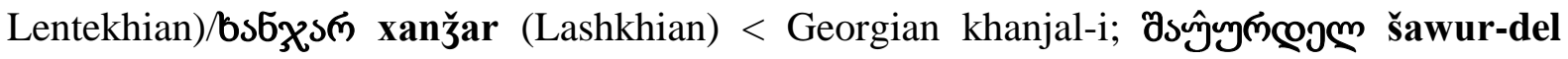
(Upper Svan) < Georgian she-varden-i; dẙgoob muzein (Lower Bal) < Georgian muzeum-

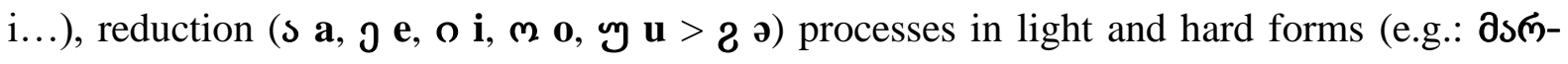

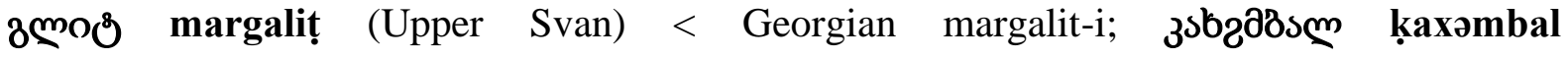

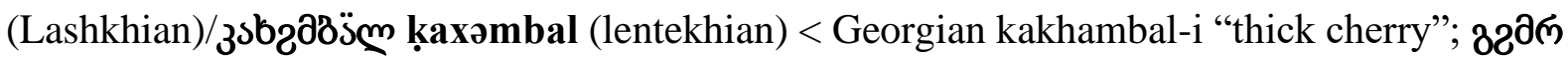

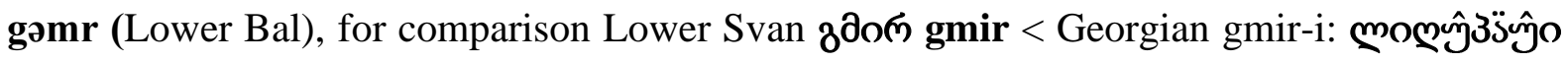

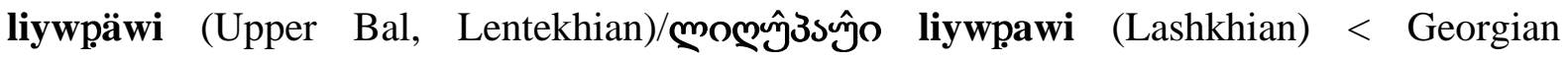

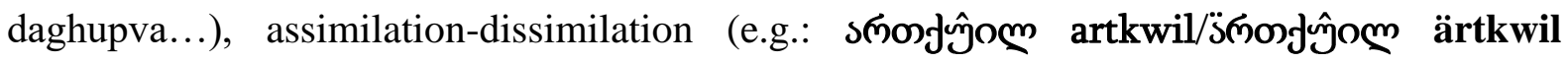

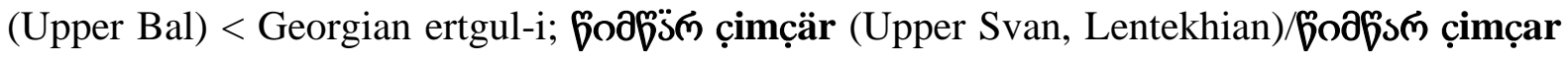

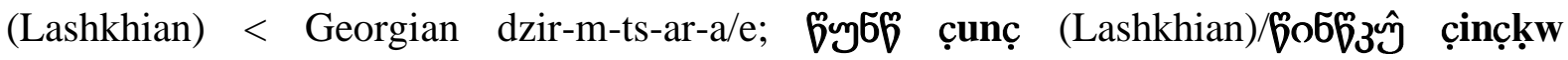
(Lentekhian) < Georgian dzunts-i...), to add the sounds (e.g.: ठs6ł banç̌ (Lower Svan) <

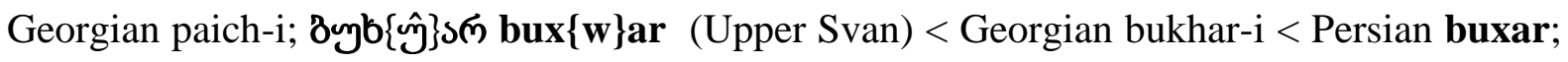

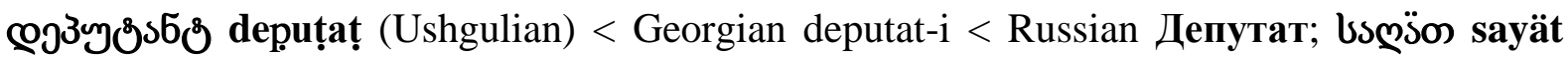

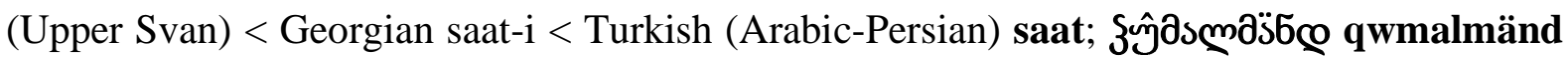

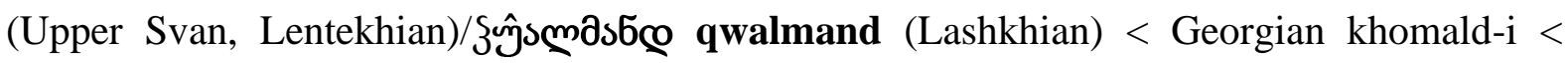
Turkish xumald...), aspiration (e.g.: 3ృ๓̈̈̈g haräg (Upper Svan) < Georgian arak-i < Arabic

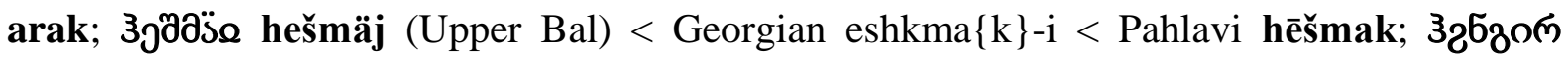
həngir (Upper Bal)/З̋ంбзо๓ hingir (Lower Bal) < Georgian unagir-i < Iranian hunagīr...), 


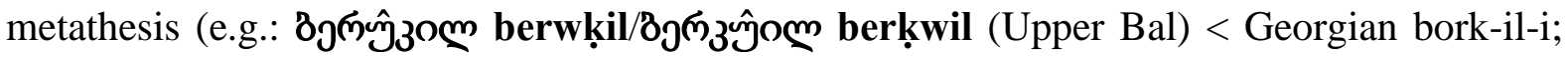

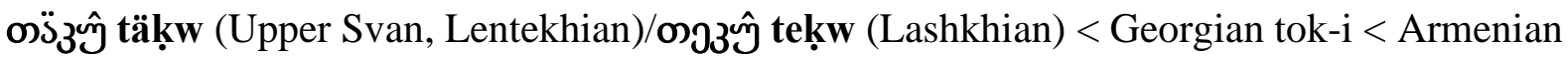
tok...) and etc.

As the observation on the material showed, the borrowed material entered in Svan not

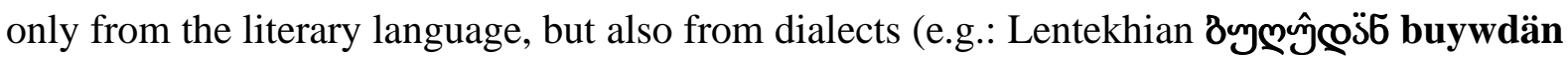
"fertile" < Georgian (Rachian) bughdavan-i "good accessible place", (Lechkhumian)

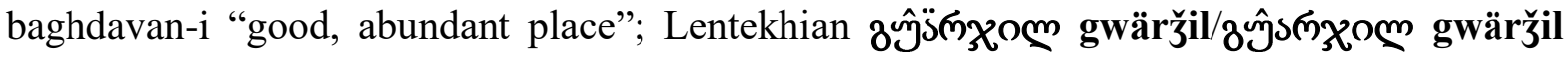
"sulgun-i - "variety of hard cheese" < Georgian (Lechkhumian) gvajil-i "sulguni - variety of

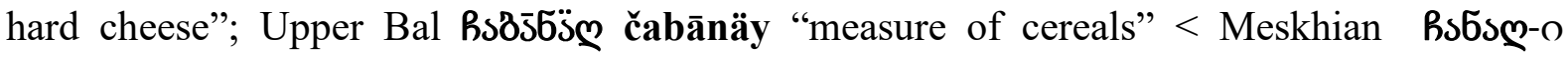
čanay-i < literary Georgian chanakh-i < Turkish çanak "crockery"; Cholur

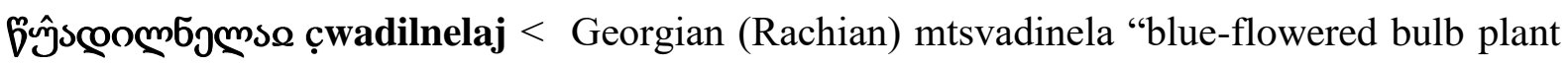
of the lily family - Tsistvala" and etc.

In this regard, the abundance of data of western dailects of Georgia is especially noticeable. There is difference even within the dialects of Svan itself: In Lashkhian and Lentekhian there are much more Georgian borrowings than in Upper Bal dialect, while in

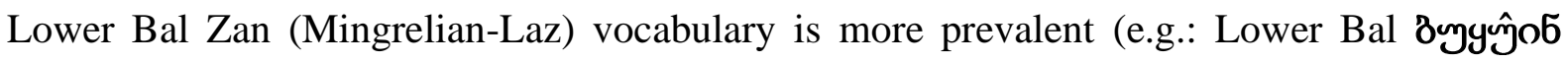
bugwin "wooden barrel for storing cheese for winter" < Zan (Mingrelian) Byyy5-o/8ypy5o bukun-i/buk'n-i "wooden utensil, barrel made specially, which are used to pour milk, to make yogurt; often to store grain (maize), flour"; Lower Bal змпззмз korḳoc < Zan

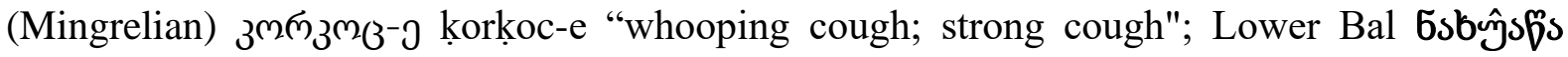
naxwaça < Zan (Mingrelian) 6sb3sfos naxvaça "crust formed on the bottom of the saucepan

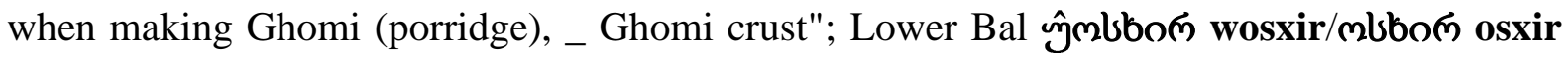

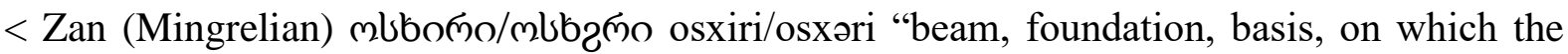
wall of the house were built"; Lower Bal Bbŷyoб@̣̈ čxwindä (Lower Bal) "a man with a twisted nose or an ugly nose" < Zan (Mingrelian) hb3o6œ- -sd-o čxvind-am-i "big-nosed, long-nosed, pointed”, Laz ßb3oбœ̧ čxvinda "big-nosed" and etc.).

Attention must be paid to the chronological flatness of the borrowed words. The situation is especially difficult when dealing with ancient borrowings, which may have been represented by sounds correspondence in Kartvelian languages: Although Georgian bろo-

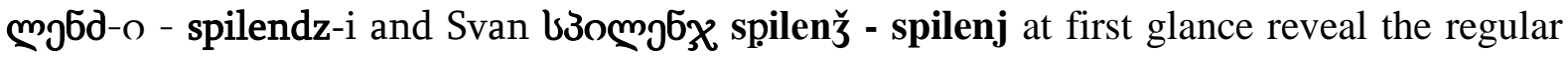


phonemes correspondence $\left(\mathbf{d z} \_\mathbf{j}\right)$, we still can not consider them as later data after the differentiation of the Pre-Georgian language, because in ancient Georgian 3ом95d-o pilendz-i (< Middle Persian *pirinz _ Andronikashvili 966, 16-18, 168, 186, 202, 262, 361365) was more common than b3omg 56 -o- spilendz-i; the latter seems relatively late and therefore, naturally, could not give correspondence in Svan. The same can be said about the

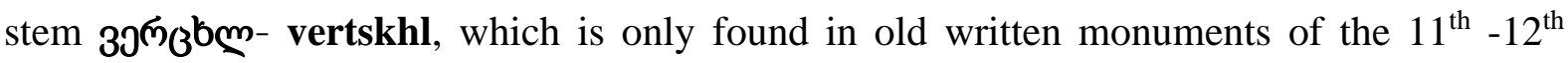
centuries, and in ancient sources this lexeme without sonant is represented in inlaut $\left(300^{6} \mathbf{c m}-\right.$ o - vertskhl-i). According to special literature (Z. Sarjveladze, H. Fenrich, G. Klimov), Svan

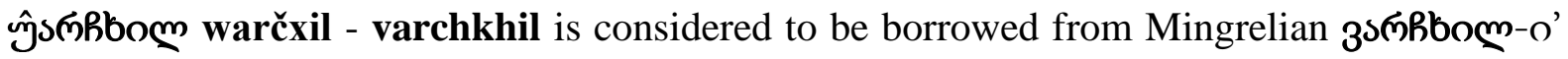
- varchchkhil-i'.

Adding sonoant in inlaut, is common phenomenon for Mingrelian. Since Georgian form $39^{m} \mathbf{3}^{\mathrm{b}} \mathrm{m}$ - vertskhl is late, obviously, we consider this stem to be derived from the common Kartvelian level. Also, despite the fact that in Svan "black colour" is conveyed by the suffix

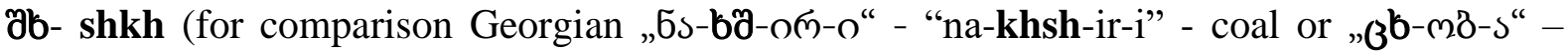
"tskh-ob-a" - to bake) expressing the root "burning" after the differentiation of the Pre-

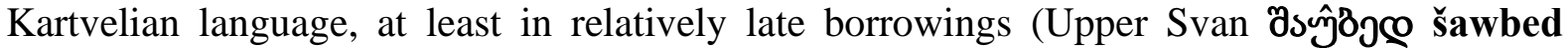

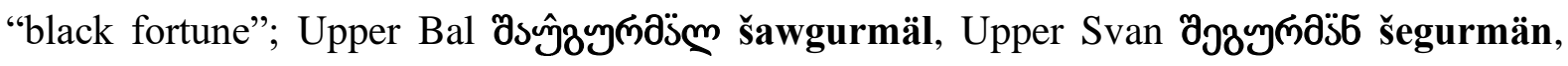

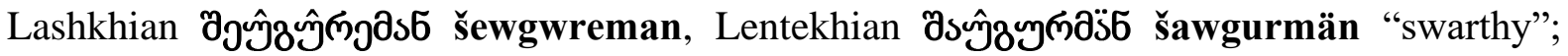

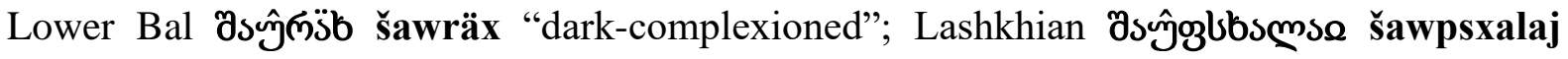
"pear variety, black pear", Shavmskhala) gs3 - shav is confirmed.

We have specially studied as borrowed religious (mainly Christian) vocabulary (e.g.: sos\&as aiazma (Upper Svan) "saint, sanctified (water") < Georgian aiazma < Greek

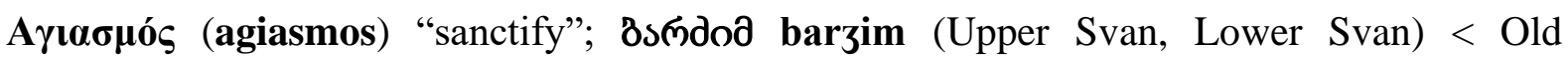
Georgian bardzim-i "church utensils having feet made of silver (or other precious metal) for

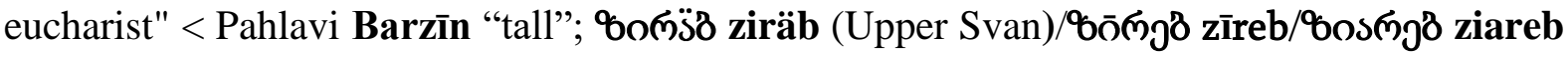

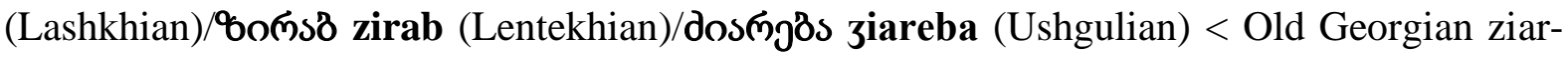

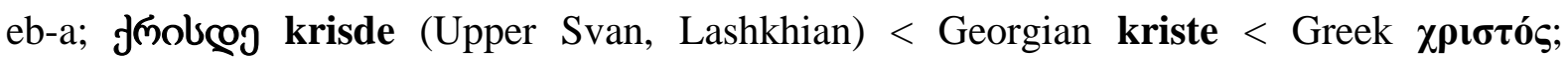

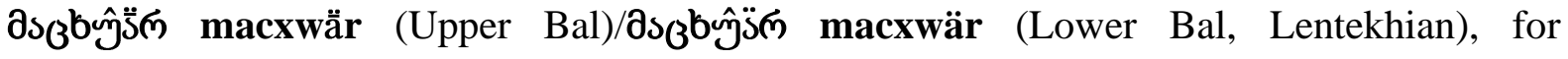

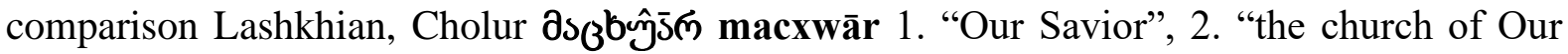
Savior" < Old Georgian ma-tskh-ov-ar-i...), as well as foreign-language toponymic material 


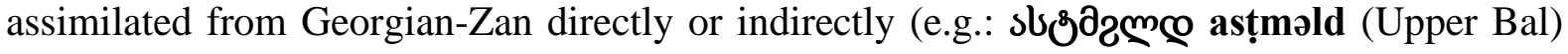

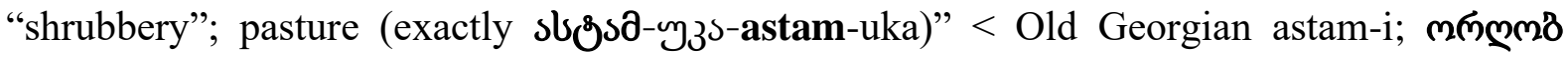

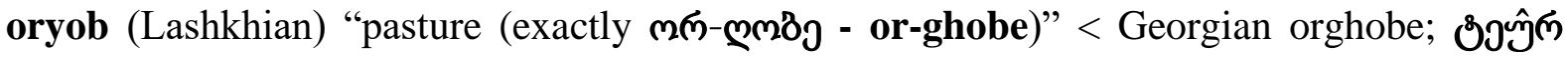

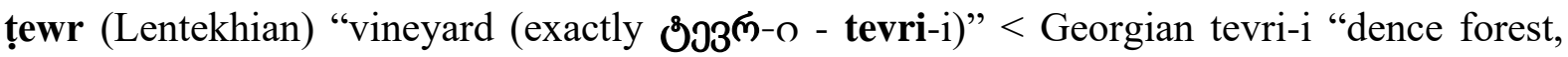
tickets"; उymm6 bulon (Lentekhian, Lakhamulian) "mountain, summer pasture of the

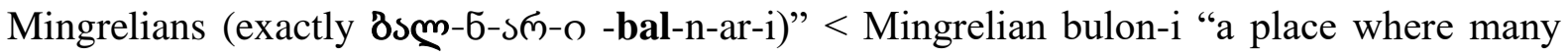

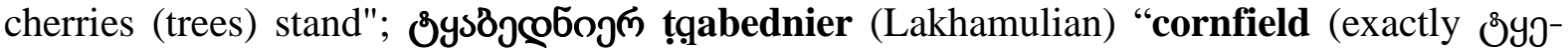

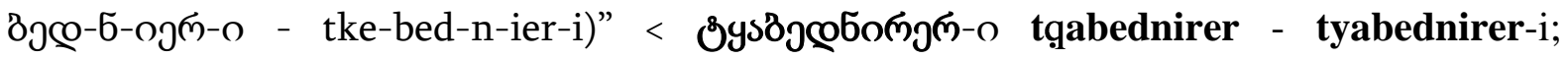

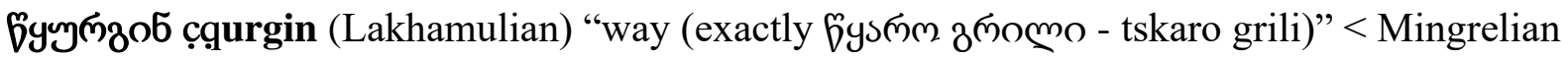

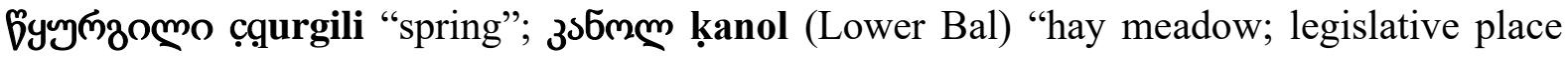

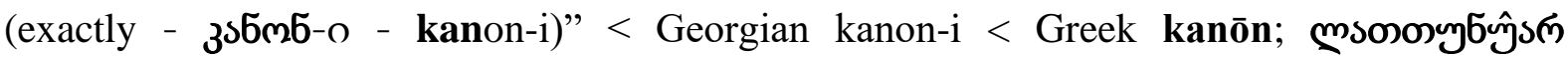
lattunwar (Lentekhian) "pasture (exactly bs-oymy56-9 - sa-tutun-e)" < Georgian tutun-i <

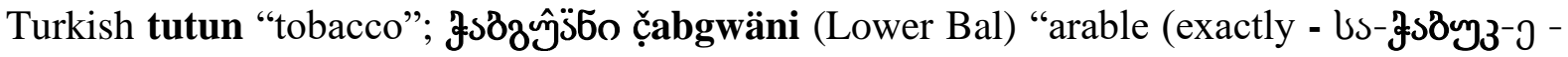

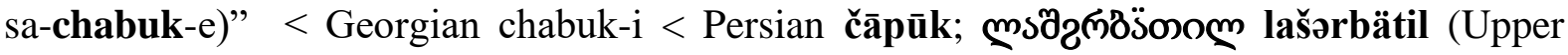

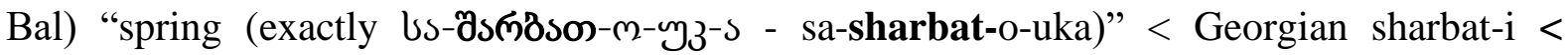

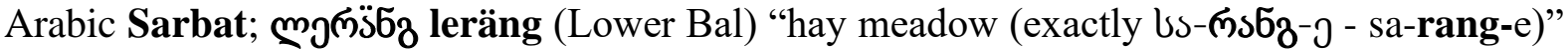
Georgian (Rachian), Mingrelian rang-i "drink made of honey, honey wine" < Ossetian rong...), most of them are presented for the first time in Kartvelological linguistics. it was interesting to study Svan hybrid (resp. crossbreed) toponyms containing borrowed anthroponyms. One of the components we have identified in most of the basic models of hybrid toponyms (mostly the first, or in this case anthroponym), as a result of a considerable amount of illustration material, as expected, turned out to be borrowed from different languages (directly or indirectly). It is known from special literature that foreign anthroponyms are found next to national names in almost all languages, and, obviously, Svan is no exception in this respect, where besides the Svan material itself, it is often foreign,

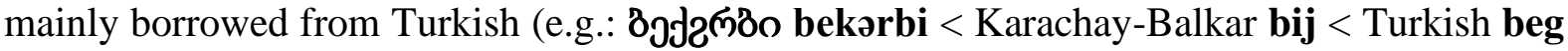

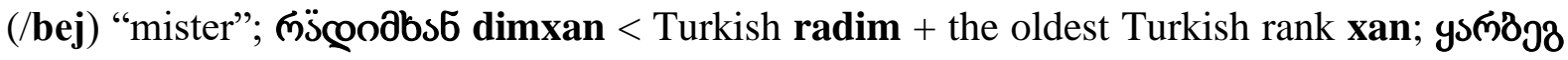
garbeg < Turkish kara "black", "brave" + beg (/bej) "mister"..), anthroponyms are also confirmed, most of which are considered to have been assimilated from Karachay-Balkar in Svan (Jikia 1973: 213). 
Exactly the language absorbed these anthroponyms and used as forming a geographical name, although along with Turkish anthroponyms we often find anthroponyms borrowed from Greek (e.g. క̈6onдm\& äntimoz (Upper Svan, Lentekhian) < Georgian antimoz-i (< Greek) "florid", blossoming"; Зวతిભூ pețre (Upper Svan, Lower Svan) <

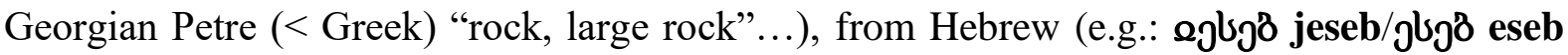
(Lower Bal) < Georgian Ioseb-i (< Old Hebrew) "reproduction", "increase"; sðßnsa abram (Upper Svan, Lower Svan) < Georgian Abram-i (< Old Hebrew) "father of heights", "raised up"...), from Russian (e.g.: ajb̈̈ mexä (Lower Bal)/aobj mixe (lakhamulian) < Georgian Mikheil-i < Russian Михаил < Greek Михаил < Old Hebrew Miqael...), from Ossetian (e.g.: bmbmsb soslan (Lower Bal) < Georgian Soslan-i (< Ossetian < Ingush) "the name of one of the heroes of the epic of the Narts" ...), from Iranian (e.g. Ӟฒhoç ärčil (Upper Svan, Lentekhian)/s(nhom arčil (Lashkhian, Cholur) < Georgian Archil-i (Iranian) "correct",

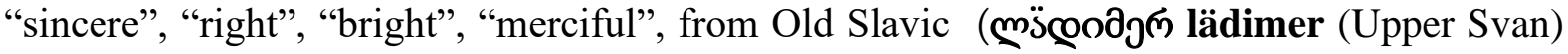
$<$ Georgian Vladimer (< Old Slavic) "owner of the country), from Arabic-Persian (วyn̊sys5 (Upper Svan) < Georgian Mirza < Arabic-Persian Amirzade "Emir's son" + Persian suffix xan (Mirzakhani)...) and etc. Borrowed anthroponyms, most of which are currently found only in toponyms and in names denoting family-branch names. Most of the foreign-language anthroponyms have been preserved by the names denoting family-branch names and, as M. Kaldani indicated, they saved them from eventual oblivion (Kaldani 1987: 304). Obviously, most of the mentioned anthroponyms are assimilated into Svan from Georgian-Zan (directly or indirectly).

\section{Conclusion:}

Clearly, our main area of interest is to determine the geographical direction of the borrowing and, if possible, the chronology, which, of course, is associated with great difficulty. Determining the chronological boundaries of borrowed words is usually difficult, especially when dealing with ancient borrowings, which may have been represented by sound correspondence in Kartvelian languages (Sagliani 2005: 218). The anthroponyms that have survived in Svan toponyms and family-branch names are of ancient formation and most of them, as already mentioned, have been preserved by 
toponyms and family-branch names. In addition, early proper nouns of Svan have undergone phonetic-semantic adaptations over time, that makes it difficult to restore the original form of analytical forms and makes it even difficult to define both chronological boundaries and the geographical direction of borrowing.

\section{NOTES:}

1 The research was conducted in 2019 within the framework of the young Scientist Research Project funded by the Shota Rustaveli National Science Foundation of Georgia _ „PhoneticalPhonological and Semantic Analysis of Loan- Words in the Svan Language" (fundamentalapplied research, appended with a dictionary)“.

\section{REFERENCES}

Andronikashvili M. (1966). Andronikashvili M., Outlines from Iranian-Georgian Linguistic Relationship. T. Publishing House of Tbilisi University. Tbilisi.

Fähnrich, H. \& Sarjveladze, Z. (2000). Etymological Dictionary of the Kartvelian Languages. Sulkhan-Saba Orbeliani State University Press, Tbilisi.

Jikia, M. (1971). Jikia M., Anthroponyms of Turkish Origin in Georgian. Science. Tbilisi. Kaldani, M. (1987). Kaldani M., Semantics and Structure of Svan Names (According to the Materials of the Chronicle of Souls): Onomastics. I. Publishing House of Tbilisi University. Tbilisi.

Klimov, G. (1998). Etomological Dictionary of the Kartvelian Languages, Berlin/New York. Machavariani G. (1965). Machavariani G., Common Kartvelian consonant system. Publishing House of Tbilisi University. Tbilisi.

Sagliani M. (2005). Sagliani M., borrowings in Svan language. Candidate's dissertation. Science. Tbilisi. 